\title{
Effect of high protein diet in activity of antioxidants and level of inflammation on sprint athlete
}

\author{
Endang Sri Wahjuni ${ }^{1, *}$, Soetanto Hartono ${ }^{2}$ \\ 1 Faculty of Sport Sciences, Surabaya State University, Surabaya, Indonesia \\ 2 Postgraduate, Surabaya State University, Surabaya, Indonesia \\ * Corresponding author: endangwahjuni@unesa.ac.id
}

\begin{abstract}
This study aims to analyze the effect of a low-carbohydrate high-protein diet to increase the level of antioxidant, decrease inflammation and improve performance of athlete. The research was carried out by experimental research methods, within the design of "Randomized Control Group Pretest Posttest Design". A sample was taken from 20 people who met the inclusion and exclusion criteria from 30 teenage athletes in PASI East Java sprints. The Data were collected by measuring the sprint results by finish photo camera and laboratory examinations to determine the levels of antioxidants (SOD) and the inflammation degree (TNF-a) in blood. The data were analyzed using multivariate technique (Manova) Hotelling's method (T2). Hypothesis testing using $a=0.05$. The results and conclusions of the study stated that the normal diet had no effect on the variables of sprint running speed, SOD and TNF-a levels. While low-carbohydrate and high-protein diet can increase SOD levels of $211.44 / \mathrm{gHb}$, reduce (TNF- $\mathrm{a}$ ) at least $0.309 \mathrm{pg} / \mathrm{ml}$, and the average increase in antioxidant activity caused by low-carbohydrate-high-protein diet is $24.989 / \mathrm{gHb}$ higher than normal diet, the decrease in the degree of inflammation is $0.196 \mathrm{pg} / \mathrm{ml}$, however, it has no effect on the speed of sprint.
\end{abstract}

\section{KEYWORDS}

inflammation; SOD; TNF; food; diet

DOI

10.14712/23366052.2021.12

\section{INTRODUCTION}

The results of several physical tests on athletes, which were held by the central KONI in order to face the Asean Games and Sea Games, indicated that their physical condition was still inadequate. Physical condition is an important element and becomes the basis for developing techniques, tactics, strategies and mental development (Santoso, 2007). One of the important factors to achieve optimal physical condition is a proper nutrition (Wilmore \& Costil, 2004). An athlete who is talented and motivated to

(c) 2021 The Authors. This is an open-access article distributed under the terms of the Creative Commons Attribution License (http://creativecommons.org/licenses/by/4.0), which permits unrestricted use, distribution, and reproduction in any medium, provided the original author and source are credited. 
train will not reach his optimal potential without making the right diet/eating choices (Maughan, 2009). It shows that the nutritional aspect is very supportive to achieve an optimal performance (Wilmore \& Costill, 2004), one of the efforts to maintain health is to observe the effect of diet on free radicals that occur due to physical exercise, it is expected that the nutritional intake contains high levels of antioxidants. Thus, it can counteract the free radicals that occur and reduce the inflammation degree. A high amount of free radicals will cause the damage of cell and tissue, therefore it can interfere with the health of an athlete and reduce the athlete's performance, it can be seen by measuring the effect on running speed.

Exercise can cause an increase in the use of oxygen, especially by contracting muscles, it cause an increase in electron leakage from mitochondria which will become ROS/RONS (radical compounds) and followed by oxidative with every possible negative consequences such as pain, damage cell and performance (Harijanto, 2006; Powers \& Jackson, 2008; Souza et al., 2005). A form of anaerobic exercise is sprint. Sprint is running at maximum speed, regardless of the covered distance (Williams, 2009). As reported by (Jówko et al., 2015) that sprinting, is a maximal exercise in short time, it causes considerable cell damage that stimulates oxidative stress, it can be prevented by antioxidants supplements (Hammouda et al., 2012; Jówko et al., 2015).

It has been explained above, that free radicals stimulate inflammation. Inflammation is a form of the body's defense system or immune system that is needed in body's defense framework to overcome infection or the entry of microbes into the body that can cause disease. However, excessive inflammation will actually interfere with the body's physiological processes. A symptoms of inflammation is indicated by the production of cytokines, one of which is TNF-a (Djauzi, 2002). In strenuous exercise there is an increase in cytokines of blood circulation. Muscle contraction stimulates the production and release of cytokines, which can affect metabolism and modify cytokine production in other organs (Pedersen et al., 2009). Beside the physical exercise, the release of TNF- $\alpha$ is also increased due to a high-carbohydrate diet (Gonzalez et al., 2012). A high intake of fruits and vegetables can reduce plasma levels of cytokines as a symptom of inflammation and oxidative stress (Root et al., 2012).

The total calories recommended by most people is a diet that contain $55-60 \%$ carbohydrates, not more than $35 \%$ fat (less than $10 \%$ saturated fat) and $10-15 \%$ protein, and it turns out that the ingredients of this diet are the most suitable support for Athletes (Kusnanik et al., 2011; Maughan, 2009; Wilmore \& Costill, 2004).

Nowadays, low-carbohydrate diet with high protein or fat is widely recommended. The use of this diet among athletes can help to change human body composition, however the effect of every athlete performance is different. The Diet Zone is a low-carb, high-protein diet to improve athletic performance. in case of swimmers at Stanford University, he won 8 gold medals in Barcelona and various swimming championships in US (Sears, 1997). This Diet zone contains macronutrients with a composition of $40 \%$ carbohydrates, $30 \%$ protein, and $30 \%$ fat, rich of fruits and vegetables, within an amount of 1735 calories, for athletes (Sears, 2001). A Research by Burke indicated that an athlete's performance will be good for high-carbohydrate diet (Burke et al., 2011). Moreover, Bosse et al's study found that, there is no significant differences between 
the control group and diet zone on blood glucose, blood lipids and treadmill exercise (Bosse et al., 2004). Based on the different opinion above, modifications were made for the diet zone, is a diet with low-carbohydrates and high-protein related to the required calories of athletes and a suitable menu for Indonesians, with a ratio of $30 \%$ carbohydrates, $40 \%$ protein $30 \%$ fat, and rice which is a source of carbohydrate replaced with vegetables and fruit, while protein is obtained from animal and vegetable proteins, by the total of 3000 calories/day.

The diet used in this study is a diet with low carbohydrates, high in protein and rich of fruits and vegetables, while antioxidants are generally enzymes formed by protein as a protection of free radicals (Ikram et al., 2009).

This study aims to determine the effect of giving a low-carbohydrates and high protein diet which can be seen in sprinter athletes by increasing running speed of laboratory for increasing antioxidant activity (SOD), decreasing inflammation (TNF- $\alpha$ ).

\section{RESEARCH METHODOLOGY}

This research is a quasi-experimental study using a research design of "Randomized Pretest-Postest Control Group Design". The target population is every youth short-distance runner, aged 13-15 years from Indonesian Athletics Association (PASI) East Java, both male and female, within an amount of 30 people.

Due to the small amount of population, the samples in this study were those who met the following inclusion and exclusion criteria. The Inclusion criteria: Male or female sprint athlete, aged 13-15 years, non-smoker, did not suffering from diabetes mellitus, have no plan for specific diet for three months before the beginning of the research and not taking any drugs that will affect neuromuscular and metabolic. Non-verbally, they are willing to take part in the research and fulfill the prescribed procedures, and sign the consent form. The number of samples obtained is the sample that meet the inclusion criteria, then divided into 2 groups with the same number or maximum difference of a sample, and the balance on the number of men and women is balanced.

The athlete's performance data was obtained by testing the $60 \mathrm{~m}$ sprint with 2 repetitions. The tool used to determine the speed is the finish photo, with the units of measurement in seconds. While the antioxidant activity data (SOD) was obtained by laboratory tests using blood serum, with laboratory examination equipment using RX Monza SD 125 manuals of $\mu / \mathrm{ml}$ and the inflammation degree with laboratory tests of blood serum and the TNFSF1 Immunoassay of $\mu / \mathrm{pg}$.

\section{Data analysis technique}

Based on the examined problems, which considering the design form in Randomized Pretest-Posttest Control Group Design, the data were analyzed using the Multivariate Analysis of Variance technique in form of Paired Comparison Hotelling's (T2) method (Johnson \& Wichern, 1992).

\section{RESULT AND DISCUSSION}

Descriptive data of actual intake subject. 
Table 1 The subject of actual intake

\begin{tabular}{l|c|c|c|c}
\hline \multirow{2}{*}{ Nutrients } & Normal Diet & & \multicolumn{2}{c}{ Low-carbohydrate, high protein diet } \\
\cline { 2 - 5 } & Average menu/day & Actual intake/day & Average menu/day & Actual intake/day \\
\hline Energy (cal) & 2235.3 & 2191.62 & 3035.93 & 2927.65 \\
\hline Protein (gram) & 146.0 & 142.69 & 216.28 & 205.61 \\
& & $(26.2 \%)$ & & $(30.2 \%)$ \\
\hline Fat (gram) & 90.7 & 89.84 & 155.08 & 151.63 \\
& & $(37.2 \%)$ & & $(50.2 \%)$ \\
\hline Carbohydrate (gram) & 204.7 & 198.80 & 141.82 & 132.99 \\
& & $(36.6 \%)$ & & $(19.2 \%)$ \\
\hline
\end{tabular}

Table 2 Descriptive analysis result of post-test differences and pre-test bound variables for normal diet and low-carbo high-protein diets

\begin{tabular}{c|l|c|c}
\hline \multicolumn{1}{|c|}{ Variant } & $\begin{array}{c}\text { Difference posttest-pretest } \\
\text { Normal Diet }\end{array}$ & $\begin{array}{c}\text { Difference between posttest-pretest } \\
\text { Low-carbo, high protein diet }\end{array}$ \\
\hline 1 & Athlete Performance (60 m sprint) & 0.3090 second & 0.1460 second \\
\hline 2 & Antioxidant activities (SOD) & $36.73 \mu / \mathrm{gHb}$ & $216.79 \mu / \mathrm{gHb}$ \\
\hline 3 & Inflamation degree (TNF-a) & $-0.3004 \mathrm{pg} / \mathrm{ml}$ & $-0.8317 \mathrm{pg} / \mathrm{ml}$ \\
\hline
\end{tabular}

\section{Data analysis}

To observe the changes in dependent variables due to normal diet, paired comparison technique analysis was performed. Based on the results of analysis on paired comparison technique Hotelling's method, it is obtained T2 $=0.5141$, while Ta $(\mathrm{p}, \mathrm{N}-1)=$ $\mathrm{T}^{0.05}(4.9)=27.202$. Because $\mathrm{T}^{2}=0.05141<27.202=\mathrm{T}^{0.05}(4.9)$, it is concluded that there is no increase in the variables of athletes performances, antioxidants and there is no decrease in inflammatory symptoms due to the normal diet.

To observe the change of dependent variable as a result of low carbo-high protein diet, paired comparison analysis technique was done. Based the analysis of paired comparison technique Hotelling's method, it is obtained $\mathrm{T}^{2}=33.326$, while $\mathrm{T}^{0.05}$ $(4.9)=27.202$. Because $\mathrm{T}^{2}=33.326>27.202=\mathrm{T}^{0.05}(4.9)$. To investigate which components of are not $0.95 \%$ simultaneous confidence intervals are used. The results of the analysis are presented in the following table below:

Table 3 The results of simultaneous confidence intervals analysis $(a=0.05)$ dependent variables on low carbo, high protein diet

\begin{tabular}{l|c|c|c|c}
\hline \multirow{2}{*}{ Diet Variant } & Dependent variable & Mean difference & \multicolumn{2}{|c}{ Simultaneous Confidence Intervals 95\% } \\
\cline { 4 - 5 } & & Coefficient & Lower limit & Upper limit \\
\hline Low Carbo- & Athlete performances (60m sprint) & 0.146 second & -0.3852 second & 0.6772 second \\
\cline { 4 - 5 } High protein diet & Antioxidant activity (SOD) & $216.79 \mu / \mathrm{gHb}$ & $211.44 \mu / \mathrm{gHb}$ & $222.1359 \mu / \mathrm{gHb}$ \\
\hline & Inflamation degree (TNF-a) & $-0.8315 \mathrm{pg} / \mathrm{ml}$ & $-1.354 \mathrm{pg} / \mathrm{ml}$ & $-0.309 \mathrm{pg} / \mathrm{ml}$ \\
\hline
\end{tabular}

Based on table 3, it can be seen that the average antioxidant value for the population begin from $211.44 / \mathrm{gHb}$ to $222.1359 / \mathrm{gHb}$, it means that the antioxidant activity 
increases at least $211.44 / \mathrm{gHb}$. for the inflammation degree of the average value of population, ranges from -1.354 to $-0.309 \mathrm{pg} / \mathrm{ml}$, it means that there is a minimum decrease of $0.309 \mathrm{pg} / \mathrm{ml}$. Therefore, low carbo, high protein diet is effective to increase an activity of antioxidant and reducing inflammation.

\section{The result of similarity test of bound variables}

The results for Pillai's Trace, Wilks' Lambda, Hotelling's Trace and Roy's Largest Root criteria, was obtained sig. $0.037<\alpha=0.05$. Thus, the mean vector for Normal diet $(\mu 1)$ is not the same as mean vector for a low-carbo, high-protein diet $(\mu 2)$. It means that there are components which the vector $\mu 1$ and vector $\mu 2$ have different values. To find out which components are different, simultaneous confidence intervals are used with a $95 \%$ confidence level obtained from the results of computer software is obtained as the following table below:

Table 4 Results of simulated confidence intervals analysis $(0.05)$ dependent variables on normal diet and low carbo, high protein diet

\begin{tabular}{l|c|c|c|c}
\hline Independent & Dependent Variable & Mean difference & \multicolumn{2}{|c}{ Simultaneous Confidence Intervals 95\% } \\
\cline { 3 - 5 } Variable & Coefficient & -0.129 second & -0.798 second & 1.416 second \\
\hline \multirow{2}{*}{ Diet } & $\begin{array}{c}\text { Athlete performances } \\
(60 \mathrm{~m} \text { sprint })\end{array}$ & & $24.989 \mu / \mathrm{gHb}$ & $228.531 \mu / \mathrm{gHb}$ \\
\cline { 2 - 5 } & Antioxidant (SOD) & $126.76 \mu / \mathrm{gHb}$ & $-0.936 \mathrm{pg} / \mathrm{ml}$ & $-0.196 \mathrm{pg} / \mathrm{ml}$ \\
\cline { 2 - 5 } & $\begin{array}{c}\text { Inflamation Degree } \\
\text { (TNF-a) }\end{array}$ & $-0.566 \mathrm{pg} / \mathrm{ml}$ & & \\
\hline
\end{tabular}

Based on table 4. the analytical results as shown in the table can be concluded as: there is no significant difference between Normal diet and low-carbo, high-protein diet in terms of improving athlete performance. There is a significant difference between Normal diet and low-carbo high-protein diet in terms of increased antioxidant activity. Furthermore, the average increase in antioxidant activity caused by the low-carbo high-protein diet is higher than what caused by normal diet. The average increase in antioxidant activity caused by low-carbo, high-protein diet at least $24.989 / \mathrm{gHb}$ more than the average increase in antioxidant activity caused by normal diet. There is a significant difference between Normal diet and the low-carbo, high-protein diet in terms of decreasing the inflammation degree. Furthermore, the average decrease in inflammation degree caused by the low-carbo, high-protein diet is higher than what it caused by Normal diet. The average decrease in the inflammation degree caused by low Carbo, high protein diet at least $0.196 \mathrm{pg} / \mathrm{ml}$ lower than the average decrease in inflammation degree caused by Normal diet.

\section{DISCUSSION}

\section{Food intake analysis}

The results of the study showed that the actual intake of food consumed by the sample was lower than what was planned before, for example, the expected amount of energy in treatment group was $3035.95 \mathrm{cal} /$ day, however the actual intake was $2927.65 \mathrm{cal} /$ day, 
and it also happen on carbohydrates, fats and proteins, in normal diet group and the treatment group, as shown in table 1 before.

Diet is influenced by several factors, including socio-cultural factors, public knowledge about healthy and balanced food consumption patterns, types of available food, food promotion factors, the acceptance of trained sensory and also psychological factors (Sirajuddin et al., 2018). There seems to be a cultural difference between participants and the arrangement of the served menu. Because mainly, the menu consists of side dishes and vegetables, without rice or it substitutes for the treatment group, and there are always leftovers on their plates. It is known that traditional foods have a high in fiber in form of vegetables and fruit which are less attractive to children and teenager. It was found that $93.6 \%$ of Indonesia's population aged over 10 years did not eat enough vegetables and fruits (Sirajuddin et al., 2018). And the psychological factor, where participants get bored quickly with the menu that is served and have to be spent, seems to be quite influential on the actual intake of participants. And psychological factor, where participants quickly get bored over the served menu that have to be spent, seems to be quite influential on the actual intake of participants. Therefore, the food intake actually consumed by the lower than the expected sample.

\section{The effect of diet analysis}

The results of the study on samples receiving normal diet treatment, within the length of treatment given in this study for 15 days, both for nutrition and exercise because it is stated that after 2 -weeks training program there will be an increase in athlete performance (Bompa \& Haff, 2009). The results of other studies also state that the length and intensity of exercise causes neural adaptation that can increase muscle strength start from 15-20 days of training (Hayashida et al., 2014). However, the results of the study by Van Zant et al. (2002) in which study subjects received a high-carbohydrate, low-fat and low-carbohydrate, high-protein diet who received moderate-intensity exercise for 6 weeks, did not show significant changes in the strength of knee at the end of the study (Van Zant et al., 2002). It is similar to the research by Fleming et al. (2003) that has the length of treatment for 6 weeks and Vogt et al. (2003), by 5 weeks of treatment. It's also known that training for a competition takes a whole year, six months, or twelve weeks (Thompson, 1991). Furthermore, the required time for training program to produce an improvement of performance, takes a long time.

It has been explained that in the first 2 weeks of the change or improvement in physical performance, it is possible that the participants have not experiences any change, and it takes longer times for the changes to be appear.

Nutritional conditioning and exercise have no visible effect on the athlete's running speed. The results of SOD measurement levels in normal diet category were much lower than low-carbohydrate high-protein diet. Also the levels of TNF-a which is one of the cytokine markers of inflammation did not experience significant changes after the sample received a normal diet and exercise, which means it was unable to reduce the inflammation degree in athletes.

The effect of a low-carbohydrate high-protein diet on increasing athlete performance and antioxidant levels and the decrease of inflammation degree obtained the average value of antioxidant activity, and the population increased at least $211.44 \mu / \mathrm{gHb}$, the degree of inflammation decreased at least $0.309 \mathrm{pg} / \mathrm{ml}$. Thus, this diet is effective on 
increasing antioxidant activity and reducing the inflammation degree, however there is no change in variable of athlete's running speed.

In low-carbohydrate high-protein diet group, the time required to run $60 \mathrm{~m}$ did not show a statistical significant change. However, in this treatment group, they could cover a distance of $60 \mathrm{~m}$ in a shorter time, which experience a decreased in speed $2.8 \%$ than normal diet group, which experienced a decrease in speed of $4.06 \%$. It indicated that high-protein diet has positive effect on running speed, because the exercise that given to both groups is the same exercise.

The decrease in speed of both normal diet group and the low carbohydrate and high protein diet is probably happen due to the lack of training time, therefore the physical condition of participants has not reached the peak yet, and the low volume and exercise intensity (Thompson, 1991). Beside, psychological factors may have a role. It is said that victory and defeat in sports often depend on the mental quality of the athlete (Raglin \& Hanin, 2000). If it is considered that psychological factors are relative same in both of the groups, then physical factors happen due to the provision of diet that supports the performance in treatment group can be understood.

In low carbohydrates, high protein diet, it has the effect of increasing the antioxidant status of the body as indicated by significant increase in SOD of $24.989 \mu \mathrm{g} / \mathrm{Hb}$, thus it can counteract free radicals, especially due to the carried out physical exercise.

For antioxidant activity (SOD) in low carbohydrates high protein diet group, the results of the analysis showed that high protein and high vegetable and fruit diet was able to increase antioxidant activity in human body. Beside vegetables and fruit provided in fairly large portions, which are a fairly high source of antioxidants, the provided protein is also quite high. It is well known that an important line of defense against harmful oxidants are enzymes including glutathione peroxidase, superoxide dismutase and catalase (Powers \& Jackson, 2008). Enzymes are formed from the availability of protein. With high antioxidant activity, it can reduce free radicals formed due to strenuous physical exercise, therefore it can improve the performance of athlete.

Some facts indicated that giving antioxidant supplements can protect the body from the muscle damage caused by the process of oxidation (Nakhostin-Roohi et al., 2008; Silva et al., 2010). It will accelerate the athlete's recovery phase, especially from endurance training and consequently improve the athlete's performance. Supplements are not a substitute for dietary fiber. Including the use of FVB (Fruit vegetable and Berry) (Bloomer \& Goldfarb, 2004). This supplement cannot replace the daily intake of fiber, which is 20-35 g each day (Lamprecht, 2015). Therefore, the intake of foods that rich in vegetables and fruit is much safer and recommended as a daily source of antioxidants.

The results of statistical analysis indicated that a low-carbo high-protein diet was able to reduce the inflammation degree (TNF- $\alpha$ ) of $0.196 \mathrm{pg} / \mathrm{ml}$. It shows that food intake in this diet group is able to reduce the inflammation process that can be formed due to the exercise. A community study indicated that consumption of a fruit and vegetables combination associated with the decreased plasma levels of five proinflammatory cytokines and biomarkers of oxidative stress and increased the capacity of antioxidant (Root et al., 2012).

Oxidative stress causes an inflammatory response of the immune system to protect body tissues. Strenuous physical exercise will cause neutrophilia and lymphopenia, 
the decrease of NK cell activity and T cell function, the decrease of salivary IgA and increase pro-inflammatory cytokines and chemokines (Nieman \& Bishop, 2006). Antioxidant diets or antioxidant supplements are known to reduce the inflammation in the athletes respiratory (Wood et al., 2012). Generally, the research used supplement which proven to reduce any inflammation (Arent et al., 2010).

Complete foods that contain more than an antioxidant are more effective at increasing the capacity of antioxidant capacity (Wood et al., 2012). Therefore, a diet that contains high natural antioxidants, is better than the use of supplements for athlete.

The analysis result on the difference of normal diet and low-carbohydrate high-protein diet on increasing athlete performance and antioxidant levels also decreasing the inflammation degree indicated significant difference between normal diet and a low-carbo high-protein diet in terms of increasing the activity of antioxidant (SOD) within the increase of average at least $24.989 \mu / \mathrm{gHb}$ more than the increase in SOD caused by normal diet, and the decrease in inflammation degree (TNF- $\alpha$ ) with an average decrease of $0.196 \mathrm{pg} / \mathrm{ml}$ lower than the average decreased in TNF- $\alpha$ caused by normal diet. This is related to the previous studies, which indicated that after 6 months of a high-protein diet compared to a high-carbohydrate diet, without physical exercise, it has an effect on the decrease in oxidative stress, higher decrease in pro-inflammatory cytokines in high-protein diet (Kitabchi et al., 2013). The decrease in TNF- $\alpha$ of low-carbohydrate high-protein group was happen due to a high-glucose diet that increase the expression of monocyte chemotractant protein - 1 (MCP-1) (Shanmugam et al., 2003). In humans MCP-1 induces chemotaxis, calcium entry into cells, upregulates adhesion molecule expression and cytokine production. In humans MCP-1 induces chemotaxis, calcium entry into cells, upregulates adhesion molecule expression and the production of cytokine. The cytokines are TNF alpha and IL $1 \beta$ (Shanmugam et al., 2003). Therefore, this low carbohydrates diet group, can reduce TNF alpha levels.

\section{CONCLUSION}

Low-carbohydrate, high-protein diet can increase antioxidant activity by $211.44 \mu / \mathrm{gHb}$, reduce the inflammation degree by $0.309 \mathrm{pg} / \mathrm{ml}$. however, it has no effect on sprint athletes running speed.

Therefore, low carbohydrates, high protein diet that rich in fruits and vegetables can be recommended for athletes, to increase running speed and improve body health by increasing antioxidant activity and reducing inflammation, it means that the level of cell damage due to free radicals that was formed during the exercise can be lowered, thereby reducing fatigue, recovery time, injuries, can support athletes to achieve the highest achievement.

\section{REFERENCES}

Arent, S. M., Pellegrino, J. K., Williams, C. A., DiFabio, D. A., \& Greenwood, J. C. (2010). Nutritional Supplementation, Performance, and Oxidative Stress in College Soccer Players. Journal of Strength and Conditioning Research, 24(4), 1117-1124.

Bloomer, R. J., \& Goldfarb, A. H. (2004). Anaerobic Exercise and Oxidative Stress: A Review. Canadian Journal of Applied Physiology, 29(3), 245-263.

Bompa, T. O., \& Haff, G. G. (2009). Periodization: Theory and Methodology of Training. 5th ed. Champaign, IL: Human Kinetics. 
Bosse, M. C., Davis, S. C., Puhl, S. M., Pedersen, M., Low, V., Reiner, L., Dominguez, T., \& Seals, N. (2004). Effects of Zone diet macronutrient proportions on blood lipids, blood glucose, body composition, and treadmill exercise performance. Nutrition Research, 24(7), 521-530.

Burke, L. M., Hawley, J. A., Wong, S. H. S., \& Jeukendrup, A. E. (2011). Carbohydrates for training and competition. Journal of Sports Sciences, 29(Supl. 1), S17-S27.

Djauzi, S. (2002). Kursus Imunologi Dasar Penyakit Infeksi. Malang: Universitas Brawijaya.

Fleming, J., Sharman, M. J., Avery, N. G., Love, D. M., Gómez, A. L., Scheett, T. P., Kraemer, W. J., \& Volek, J. S. (2003). Endurance Capacity and High-Intensity Exercise Performance Responses to a High-Fat Diet. International Journal of Sport Nutrition and Exercise Metabolism, 13(4), 466-478.

Gonzalez, Y., Herrera, M. T., Soldevila, G., Garcia-Garcia, L., Fabián, G., Pérez-Armendariz, E. M., Bobadilla, K., Guzmán-Beltrán, S., Sada, E., \& Torres, M. (2012). High glucose concentrations induce TNF- $\alpha$ production through the down-regulation of CD33 in primary human monocytes. BMC Immunology, 13(1), 19.

Hammouda, O., Chtourou, H., Chaouachi, A., Chahed, H., Ferchichi, S., Kallel, C., Chamari, K., \& Souissi, N. (2012). Effect of Short-Term Maximal Exercise on Biochemical Markers of Muscle Damage, Total Antioxidant Status, and Homocysteine Levels in Football Players. Asian Journal of Sports Medicine, 3(4), 239-246.

Harijanto (2006). Antioksidan dan Latihan Olahraga. Jurnal Kedokteran YARSI, 14(1), 70-77.

Hayashida, I., Tanimoto, Y., Takahashi, Y., Kusabiraki, T., \& Tamaki, J. (2014). Correlation between Muscle Strength and Muscle Mass, and Their Association with Walking Speed, in Community-Dwelling Elderly Japanese Individuals. PLoS ONE, 9(11), e111810.

Ikram, E. H. K., Eng, K. H., Jalil, A. M. M., Ismail, A., Idris, S., Azlan, A., Nazri, H. S. M., Diton, N. A. M., \& Mokhtar, R. A. M. (2009). Antioxidant capacity and total phenolic content of Malaysian underutilized fruits. Journal of Food Composition and Analysis, 22(5), 388-393.

Johnson, R., \& Wichern, D. (1992). Applied Mulrivariate Statistical Analysis. Pretience Hall.

Jówko, E., Długołęcka, B., Makaruk, B., \& Cieśliński, I. (2015). The effect of green tea extract supplementation on exercise-induced oxidative stress parameters in male sprinters. European Journal of Nutrition, 54(5), 783-791.

Kitabchi, A. E., McDaniel, K. A., Wan, J. Y., Tylavsky, F. A., Jacovino, C. A., Sands, C. W., Nyenwe, E. A., \& Stentz, F. B. (2013). Effects of High-Protein Versus High-Carbohydrate Diets on Markers of -Cell Function, Oxidative Stress, Lipid Peroxidation, Proinflammatory Cytokines, and Adipokines in Obese, Premenopausal Women Without Diabetes: A randomized controlled trial. Diabetes Care, 36(7), 1919-1925.

Kusnanik, N., Nasution, J., \& Hartono, S. (2011). Dasar-dasar Fisiologi Olahraga. Unesa: Unesa University Press.

Lamprecht, M. (2015). Antioxidants in Sport Nutrition. Boca Raton.

Maughan, R. J. (2009). Nutrition Needs of Athlets. In: The Olympic Textbook of Science in Sport. Wiley-Blackwell.

Nakhostin-Roohi, B., Babaei, P., Rahmani-Nia, F., \& Bohlooli, S. (2008). Effect of vitamin $\mathrm{C}$ supplementation on lipid peroxidation, muscle damage and inflammation after 30-min exercise at $75 \% \mathrm{VO}_{2} \max$. The Journal of Nutrition, 48(2), 217-224.

Nieman, D. C., \& Bishop, N. C. (2006). Nutritional strategies to counter stress to the immune system in athletes, with special reference to football. Journal of Sports Sciences, 24(7), 763-772.

Pedersen, B. K., Ostrowski, K., Rohde, T., \& Bruunsgaard, H. (2009). The cytokine response to strenuous exercise. Canadian Journal of Physiology and Pharmacology, 76(5), 505-511.

Powers, S. K., \& Jackson, M. J. (2008). Exercise-Induced Oxidative Stress: Cellular Mechanisms and Impact on Muscle Force Production. Physiological Reviews, 88(4), 1243-1276. 
Raglin, J. S., \& Hanin, Y. L. (2000). Competitive anxiety. In: Y. L. Hanin (Ed.), Emotions in sport (pp. 93-111). Human Kinetics.

Root, M. M., McGinn, M. C., Nieman, D. C., Henson, D. A., Heinz, S. A., Shanely, R. A., Knab, A. M., \& Jin, F. (2012). Combined Fruit and Vegetable Intake Is Correlated with Improved Inflammatory and Oxidant Status from a Cross-Sectional Study in a Community Setting. Nutrients, 4(1), 29-41.

Santoso, S. (2007). Kondisi Fisik Prima Sama Dengan Emas PON? Buletin KONI DIY.

Sears, B. (1997). Mastering The Zone. HarperCollins Publishers, Inc.

Sears, B. (2001). The Top 100 zone foods. Harper Collins Publisher, Inc.

Shanmugam, N., Reddy, M. A., Guha, M., \& Natarajan, R. (2003). High Glucose-Induced Expression of Proinflammatory Cytokine and Chemokine Genes in Monocytic Cells. Diabetes, 52(5), 1256-1264.

Silva, L. A., Pinho, C. A., Silveira, P. C. L., Tuon, T., De Souza, C. T., Dal-Pizzol, F., \& Pinho, R. A. (2010). Vitamin E supplementation decreases muscular and oxidative damage but not inflammatory response induced by eccentric contraction. The Journal of Physiological Sciences, 60(1), 51.

Sirajuddin, Surmita, \& Astuti, T. (2018). Survey Konsumsi Pangan (Rezkina (ed.)).

Souza, T., Oliviera, Pereira, B. (2005). Physical exercise and oxidative stress, effect of intense physical exercise on urinary chemiluminescence and plasmatic malondialdehyde. Revista Brasileira de Medicina do Esporte, 11(1), 97-101.

Thompson, P. (1991). Introduction to Coaching Theory. International Amateur Athletic Federation.

Van Zant, R. S., Conway, J. M., \& Seale, J. L. (2002). A moderate carbohydrate and fat diet does not impair strength performance in moderately trained males. The Journal of Sports Medicine and Physical Fitness, 42(1), 31-37.

Vogt, M., Puntschart, A., Howald, H., Mueller, B., Mannhart, C., Gfeller-Tuescher, L., Mullis, P., \& Hoppeler, H. (2003). Effects of Dietary Fat on Muscle Substrates, Metabolism, and Performance in Athletes. Medicine \& Science in Sports \& Exercise, 35(6), 952-960.

Williams, C. (2009). Physiological Demands of Sprinting and Multiple-Sprint Sports. In: Maughan, R. J. (Ed.), Olympic Textbook of Science in Sport (pp. 25-42). Wiley-Blackwell.

Wilmore, J. H., \& Costill, D. L. (2004). Physiology of sport and exercise. Champaign, IL: Human Kinetics.

Wood, L. G., Garg, M. L., Smart, J. M., Scott, H. A., Barker, D., \& Gibson, P. G. (2012). Manipulating antioxidant intake in asthma: a randomized controlled trial. The American Journal of Clinical Nutrition, 96(3), 534-543. 